\title{
Oral single dose of allopurinol in thoroughbred foals born from mares with placentitis
}

\author{
Administração de alopurinol por via oral de dose única em \\ potros nascidos de éguas com placentite
}

\author{
Luciana Oliveira de Araujo ${ }^{I^{*}}$ Carlos Eduardo Wayne Nogueira ${ }^{I I}$ Fernanda Maria Pazinato \\ Friedrich Frey Junior ${ }^{\text {III }}$ Silvano Costa Paixão ${ }^{\text {III }}$ Letícia da Silva Souza $^{\text {IV }}$ Bruna da Rosa Curcio $^{\text {II }}$
}

\section{ABSTRACT}

The aim of this study was to evaluate the effects of Allopurinol in foals born from mares with placentitis. Twenty foals were assigned into two groups: Healthy foals $(n=10)$, born from healthy mares and Placentitis foals $(n=10)$, born from mares with placentitis. Five foals from each group were randomly assigned to a treatment or control group. Treatment groups received Allopurinol (40mg $\mathrm{kg}^{-1}$ orally six hours after birth). Blood samples were collected for estimation of hematological variables and serum concentration of calcium, chloride, creatinine, phosphorus, glucose, lactate and magnesium. Placentitis foals presented leukopenia and neutropenia when compared with Healthy foals, at birth. The white blood cell (WBC) count was lower in the Placentitis foals untreated at 12 hours. No adverse effects related to the use of Allopurinol were detected. Treated Placentitis foals showed higher serum calcium and glucose levels within 12 hours than untreated Placentitis foals. Administration of Allopurinol PO in foals born from mares with placentitis did not result in adverse effects and can help in stabilizing serum calcium and glucose levels.

Key words: neonatology, antioxidant, therapeutic, biochemical, hematology.

\section{RESUMO}

Este estudo teve por objetivo avaliar os efeitos da administração por via oral de Alopurinol em potros nascidos de éguas com placentite. Vinte potros foram divididos em dois grupos: potros saudáveis $(n=10)$, nascidos de éguas sem placentite, e potros placentite $(n=10)$, nascidos de éguas com placentite. Cinco potros de cada grupo foram selecionados aleatoriamente para compor o grupo tratado ou controle. Os grupos tratados receberam Alopurinol (40mg $\mathrm{kg}^{-}{ }^{l} \mathrm{PO} \mathrm{na}$ sexta hora de vida). Foram coletadas amostras sanguíneas para realização de análise hematológica e avaliação das concentrações séricas de cálcio, cloretos, creatinina, fósforo, glicose, lactato e magnésio. Os potros placentite apresentaram leucopenia e neutropenia, comparado com os potros saudáveis no momento do nascimento. O grupo placentite não tratado apresentou leucopenia no momento 12 horas. Não foram observados efeitos adversos relacionados ao uso do Alopurinol. O grupo placentite tratado apresentou maiores concentrações de cálcio e glicose em relação ao grupo placentite não tratado, nas 12 horas. A administração de Alopurinol por via oral em dose única em potros nascidos de éguas com placentite não resultou em efeitos adversos e pode ter contribuído para a estabilização dos níveis de cálcio e glicose.

Palavras-chave: neonatologia, antioxidante, terapêutica, bioquímica, hematologia.

\section{INTRODUCTION}

The mortality of foals born from mares with placental alterations represents the most common cause of foal loss in equine breeding (BUCCA, 2006). These foals can range from extremely early with small size and organ function incompatible with life to a full-size foal nearer to full-term gestation with minimal effects (BAIN, 2004).

Foals born from mares with placental abnormalities are at-risk foals (McAULIFFE, 2008). The impact of maternal or placental

\footnotetext{
'Programa de Pós-graduação em Veterinária (PPGV), Universidade Federal de Pelotas (UFPel), Campus Universitário, s/n, CP 354, 96010-610, Pelotas, RS, Brasil. E-mail: luaraujo_sm@hotmail.com. *Corresponding author.

"Departamento de Clínicas Veterinária, Faculdade de Veterinária, Universidade Federal de Pelotas (UFPel), Capão do Leão, RS, Brasil.

"IIHaras Santa Maria de Araras, Aceguá, RS, Brasil.

${ }^{\text {IV } D e p a r t a m e n t o ~ d e ~ M e d i c i n a ~ V e t e r i n a ́ r i a, ~ U n i v e r s i d a d e ~ F e d e r a l ~ d e ~ P e l o t a s ~(U F P e l), ~ C a p a ̃ o ~ d o ~ L e a ̃ o, ~ R S, ~ B r a s i l . ~}$
} 
disorders on the intrauterine environment generally results in fetal or neonatal compromise, due to one or a combination of three mechanisms: hypoxia, infection, and derangement of in utero development (BUCCA, 2006). Asphyxia is the result of impaired oxygen delivery to cells and usually results from a combination of hypoxemia and ischemia (VAALA, 1999). Pure hypoxemia implies a decrease in oxygen concentration in blood with preservation of blood flow, which allows organs to respond by increasing their efficiency of extracting oxygen from the circulation. Experimental studies suggested that the most deleterious effects to the nervous system after acute hypoxic-ischemic insult occur during the reperfusion phase, during which cytotoxic free radicals are formed (VAALA, 1999). Accumulation of hypoxanthine metabolites in the brain during the hypoxic period induces the additional production of superoxides and hydroxyl radicals (oxidative stress) (INDER \& VOLPE, 2000). Experimental and clinical studies in human neonatology have proposed several drugs as alternative therapies to help block the progression of damage and/or improve the repair of injured tissue (GONZALES \& FERRIERO, 2009). Based on studies in human neonatology, a component therapy approach was developed to treat at-risk foals that include antioxidants as Allopurinol and neuroprotective medications.

The aim of this study was to evaluate hematological and serum biochemical parameters in neonatal foals born from mares with placentitis, following the administration of a single dose of Allopurinol PO.

\section{MATERIALS AND METHODS}

The study was performed on a Thoroughbred farm. All mares were maintained in a semi-extensive system and were observed daily, during feeding, for clinical signs of placentitis as: vaginal discharge and premature udder development. Monthly, transrectal ultrasound examination was performed for fetal and placental assessment. For mares with clinical signs and/or thickening and placental separation (RENAUDIN et al., 1997) it was given Trimethoprim Sulfamethoxazole (Trissulfin, Ouro Fino Agronegócio, SP, BR) $25 \mathrm{mg} \mathrm{kg}^{-1}$, every 12 hours intravenously for 10 days, flunixin meglumine (Desflan, Ouro Fino Agronegócio, SP, BR) $1.1 \mathrm{mg} \mathrm{kg}^{-1}$ every 12 hours intravenously for 7 days, and altrenogest (Regumate, Merck Animal
Health Corporate Headquarters, New Jersey, USA) $0.088 \mathrm{mg} \mathrm{kg}^{-1}$ every 24 hours orally until delivery.

The foaling was monitored. Immediately after parturition, colostrum samples were collected for quality assessment with a handheld refractometer (Brix 0-50\% sugar refractometer) and fetal membranes were weighed and grossly evaluated. Samples were obtained from the pregnant horn, non-pregnant horn, uterine bifurcation, uterine body, three parts of umbilical cord, and cervical star area. Any other area that was gross abnormal was also sampled. Placentitis was confirmed when the histologic evaluation of the placenta showed more than one area of inflammatory infiltrates (HONG, 1993).

A total of twenty mares/foals were selected for the current study, and assigned in two groups: Healthy group $(n=10)$ and Placentitis group $(n=10)$. At birth, foals were submitted to clinical evaluation with assessment of neuromuscular reflexes and behavioral signs, as described by CURCIO \& NOGUEIRA (2012). Venous blood was collected by puncturing the jugular vessel at birth (0h) and at 6, 12 and 24 hours of life. Samples were collected in tubes containing EDTA for evaluation of red blood cells (RBC), hemoglobin count (HB), platelet count $(\mathrm{PT})$, packed cell volume (PCV), white blood cell (WBC) and granulocytes, lymphocytes and monocytes measures in an automatic analyzer (Mindray. Model bc2800vet, Nhansan, China). Blood samples that were collected in tubes without anticoagulant were centrifuged (1000rpm, 15min), and serum aliquots were separated, placed in microtubes and frozen at $-80^{\circ} \mathrm{C}$ for later analysis. Serum levels were evaluated for glucose, lactate, chlorides, magnesium, creatinine, phosphorus and calcium using spectrophotometric diagnostic kits (Labtest Diagnóstica S.A, Minas Gerais, Brasil). Samples were evaluated in a semi-automatic biochemical system (Model CELM SB190, Celm Cia Equipadora de Laboratórios Moderno, SP, BR).

Foals were assigned into two groups: 1) Healthy foals $(n=10)$, foals were born from eutocic delivery of mares without gestational or placental changes at histologic evaluation, 2) Placentitis foals $(n=10)$, foals born from eutocic delivery of mares with confirmed placentitis at histologic evaluation. At sixth hour of life, five foals from each group were randomly assigned to receive Allopurinol (Allopurinol 300mg, Medley Indústria Farmacêutica LTDA, SP, BR.) in a single dose (40 $\mathrm{mg} \mathrm{kg}^{-1}$ orally). Ten remaining animals did not receive any medication and served as the healthy 
and placentitis control groups. The single dose used was established from neonatal humans studies with severe asphyxia, by using a single high dose of Allopurinol (40mg kg-1 intravenously) (BAIN, 2004). Foals did not receive any other medication during the first 24 hours of life.

Results are demonstrated by mean + standard error (SE). All variables were submitted to Shapiro-Wilk normality test. For comparison of data from Healthy and Placentitis foals, Student's t-test was conducted for quantitative variables and a chisquare test for categorical variables. It was performed analysis of variance (AOV General) in a completely randomized design arranged in $4 \times 4$ factorial to compare the effect of time and treatment and even interactions between groups. For multiple comparison between means were used post-hoc least-significant difference (LSD) test. The statistical analysis was conducted using standard software (Statistix 9.0. Analytical Software, Tallahassee, Florida, USA). Significance was set at $\mathrm{P} \leq 0.05$.

\section{RESULTS}

Results (mean $\_$SE) of neuromuscular reflexes ( $\mathrm{min}$ ) and behavioral signs ( $\mathrm{min}$ ) in Healthy and Placentitis foals $(\mathrm{P}>0.05)$ were, respectively: Nurse $(54.20 \pm 5.29$ vs $45.40 \pm 5.55)$, meconium passage
$(61.50 \pm 7.26$ vs $42.20 \pm 7.00)$, Sternal recumbency

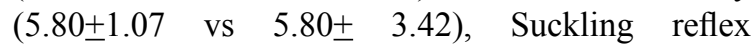
$(33.70 \pm 3.29$ vs $33.30 \pm 2.67)$ and Stand $(32.20 \pm 2.81$ vs $39.70 \pm 10.35)$. There was no difference in the quality of colostrum offered to Healthy $(28.9+1.97$ Brix) and Placentitis (24.8 \pm 2.24 Brix) foals.

Table 1 shows the values for hematological and biochemical evaluation of foals at birth. The $\mathrm{WBC}$ and the granulocytes were lower in the untreated Placentitis foals at 12 hours $(\mathrm{P}<0.05)$. At 24 hours, there was no difference between groups in WBC and granulocyte measurements $(\mathrm{P}>0.05)$ (Figure 1). Placentitis group that received treatment showed higher serum levels of calcium within 12 hours $(\mathrm{P}<0.05)$. There was a progressive reduction in the amount of calcium in groups up to 24 hours. In all groups, there was a reduction in the amount of chloride from 12 hours. It was observed higher concentrations in serum creatinine in Treated Placentitis foals at times 0 and 6 hours, with reduction to normal values at 12 and 24 hours. All foals showed a progressive reduction in creatinine values during 24 hours, and no difference between the groups was observed at different time-points $(\mathrm{P}>0.05)$. Treated Placentitis foals maintained stable values of phosphorus at 6 and 12 hours, while Untreated Placentitis foals showed a reduction at 12 hours $(\mathrm{P}<0.05)$ (Figure 2).

Table 1 - Mean + SE for gestational length, hematology and biochemistry at the birth in Healthy and Placentitis foals previous to administration of the treatment with Allopurinol.

\begin{tabular}{|c|c|c|c|}
\hline Parameters & Healthy foals $\left(\right.$ Mean $\_$SE) & Placentitis foals (Mean $+\mathrm{SE})$ & Reference range \\
\hline Gestational age (days) & $351+3.06$ & $340+5.10$ & $315-388$ \\
\hline Red blood cells $\left(\times 10^{12} \mathrm{~L}^{-1}\right)$ & $9.56 \pm 0.17$ & $9.14 \pm 0.45$ & $6.5-9.99^{*}$ \\
\hline Hemoglobin $\left(\mathrm{g} \mathrm{L}^{-1}\right)$ & $146 . \overline{7} 0 \pm 2.16$ & $138 . \overline{7} \pm 5.75$ & $134-199^{*}$ \\
\hline Hematocrit (\%) & $39.70 \pm 0.50$ & $38.72 \pm 1.71$ & $33.0-48.0^{*}$ \\
\hline Total Leukocytes $\left(\mathrm{mm}^{3}\right)$ & $8450 \pm 660.68^{\mathrm{a}}$ & $5650 \pm 881.07^{\mathrm{b}}$ & $5000-12600^{*}$ \\
\hline Granulocytes $\left(\mathrm{mm}^{3}\right)$ & $5790+566.7^{\mathrm{a}}$ & $3650 \pm 773.7^{\mathrm{b}}$ & $2750-8190^{*}$ \\
\hline Lymphocytes $\left(\mathrm{mm}^{3}\right)$ & $2280 \pm 367.51$ & $1760 \pm 259.57$ & $1750-5670^{*}$ \\
\hline Platelets $\left(\times 10^{9} \mathrm{~L}^{-1}\right)$ & $283.40 \pm 18.50$ & $248.10 \pm 29.50$ & $115-450^{*}$ \\
\hline Mean Corpuscular Volume (fl) & $41.59 \pm 1.60$ & $42.58+2.02$ & $37-45^{*}$ \\
\hline Mean corpuscular hemoglobin concentration $\left(\mathrm{g} \mathrm{L}^{-1}\right)$ & $369.60 \pm 21.1$ & $358.50 \pm 20.3$ & $330-390^{*}$ \\
\hline Calcium $\left(\mathrm{mg} \mathrm{dL}^{-1}\right)$ & $13.34 \pm 0.35$ & $12.91 \pm 0.38$ & $10.6-14.52^{*}$ \\
\hline Chloride $\left(\mathrm{mEq} \mathrm{L}^{-1}\right)$ & $124.70 \pm 7.59$ & $108.60 \pm 2.73$ & $91.6-110.5^{*}$ \\
\hline Creatinine $\left(\mathrm{mg} \mathrm{dL}^{-1}\right)$ & $2.75 \pm 0.23$ & $3.42+0.83$ & $2.0-4.0^{*}$ \\
\hline Phosphorus (mg dL $\left.{ }^{-1}\right)$ & $5.98+0.20$ & $5.97 \pm 0.32$ & $3.8-7.4^{*}$ \\
\hline Glucose $\left(\mathrm{mg} \mathrm{dL}^{-1}\right)$ & $96.40 \pm 6.72$ & $85.9 \overline{7} \pm 9.65$ & $78-112^{*}$ \\
\hline Lactate $\left(\mathrm{mg} \mathrm{dL}^{-1}\right)$ & $38.21+4.55$ & $35.54+5.20$ & $1.9-5.7^{*}$ \\
\hline Magnesium $\left(\mathrm{mg} \mathrm{dL}^{-1}\right)$ & $2.15 \pm 0.09$ & $2.22 \pm 0.14$ & $0.6-4.2^{*}$ \\
\hline
\end{tabular}

${ }^{\mathrm{a}, \mathrm{b}}$ Different superscript letters in rows indicate a statistically significant difference between the two groups by the Student tes $(\mathrm{P}<0,05)$. $^{*}$ Source: Hagyard Equine Medical Institute. Clinical Laboratory. Normal reference values for equines from birth. 


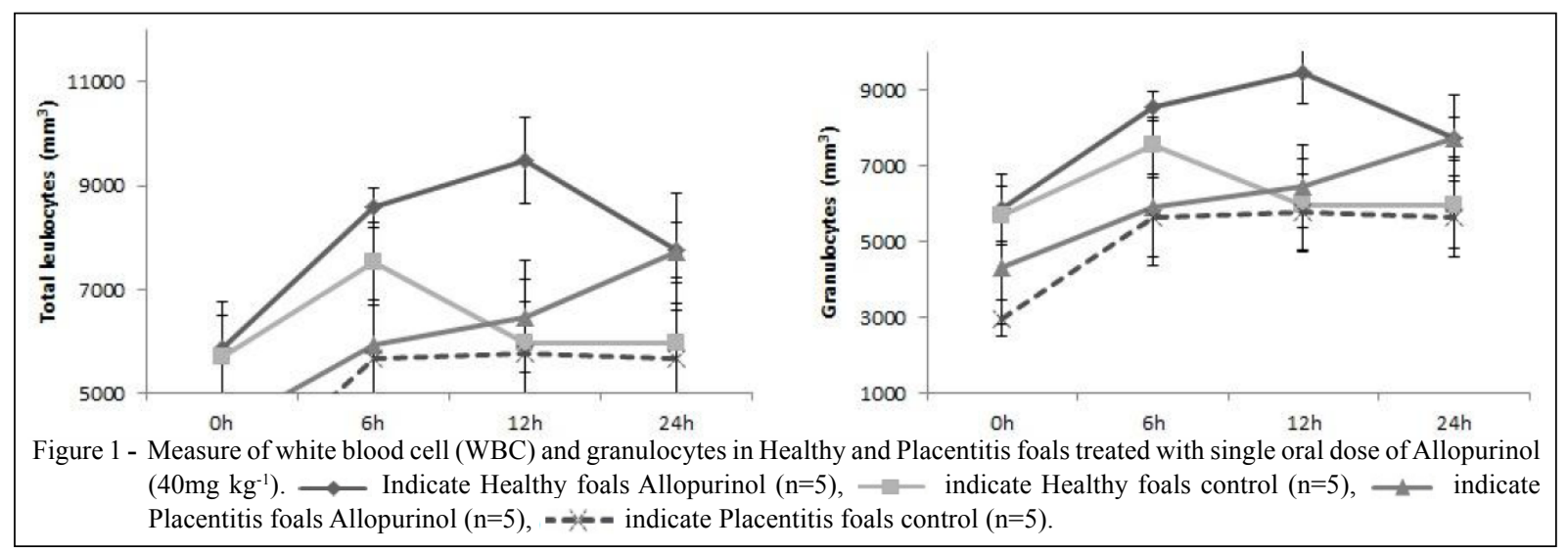

All foals in the study showed an increase in serum glucose concentration from 6 hours, with stabilization at 12 and 24 hours $(\mathrm{P}<0.05)$. The treated Placentitis group showed higher glucose levels compared to untreated foals of that group. Healthy foals showed a significant reduction in lactate levels at 12 and 24 hours, regardless of treatment $(\mathrm{P}<0.05)$. Placentitis foals did not show a reduction in the values during time, regardless of treatment $(\mathrm{P}>0.05)$. No difference between groups at various time-points was observed for evaluations of glucose, lactate and serum creatinine $(\mathrm{P}>0.05)$ (Figure 3 ).

\section{DISCUSSION}

The leukopenia with neutropenia observed in the Placentitis foals group at birth moment proves that animals had some degree of impairment even without the manifestation of clinical alterations at birth. In Healthy foals, WBC count increases significantly after birth, primarily associated with an increase in circulating neutrophils (CURCIO \& NOGUEIRA, 2012). In this study, foals evaluation of birth time to observation of postural and behavioral reflexes showed values similar to those described in the literature (CURCIO \& NOGUEIRA, 2012), with the exception of time to show a sucking reflex, which was higher in the present study. The time intervals from birth to manifestation of specific reflexes in foals are used as parameters for evaluating the newborn health and may vary according to the degree of monitoring and manipulation in foaling (CURCIO \& NOGUEIRA, 2012). There was not observed hypersensitivity, skin or hematological reactions related to the use of Allopurinol in foals as described in neonates humans (BENDERS et al., 2006).
Elevations in serum creatinine may also be a transient finding in asphyxiated foals or foals delivered from mares with placentitis (SCHOTT, 2011); however, this usually reflects placental pathology rather than renal disease in the foal (AUSTIN, 2013). Progressive reduction in serum lactate values at birth was observed up to 24 hours, but differences between groups at different timepoints were not identified. Placentitis group showed a smaller reduction in values than Healthy foals, regardless of the treatment administered. The slight reduction in lactate levels in the Placentitis foals may be related to hypoxia and low blood perfusion (CORLEY et al., 2005). The lactate concentration is usually increased at birth but reduces to mean values of $18.92 \mathrm{mg} \mathrm{dl}^{-1}$ (9.0 to $33.33 \mathrm{mg} \mathrm{dl}^{-1}$ ) within $24-72$ hours of life (AUSTIN, 2013).

Progressive increase in glucose values after birth reported in this study is considered normal for foals. At birth, the serum glucose can be $50 \%$ lower than the maternal serum glucose, but after the first feeding; significant increases in glucose levels occur during the first 48 hours and remain higher than in adult animals for 2-3 months (WILKINS, 2011). In the untreated group, lower amounts of glucose can be explained by the fact that in foals suffering from hypoxia, a depletion of glucose occurs and can cause hypoglycemia in the early hours of life (KOTERBA, 1990). Placentitis group foals that received treatment showed maintenance of normal values of glucose, which may be related to the action of allopurinol in reducing cellular damage.

In all groups, there was a significant reduction in calcium, with a stabilization time of 24 hours, as described in literature (WILKINS, 2011). In foals that received treatment, calcium values were 


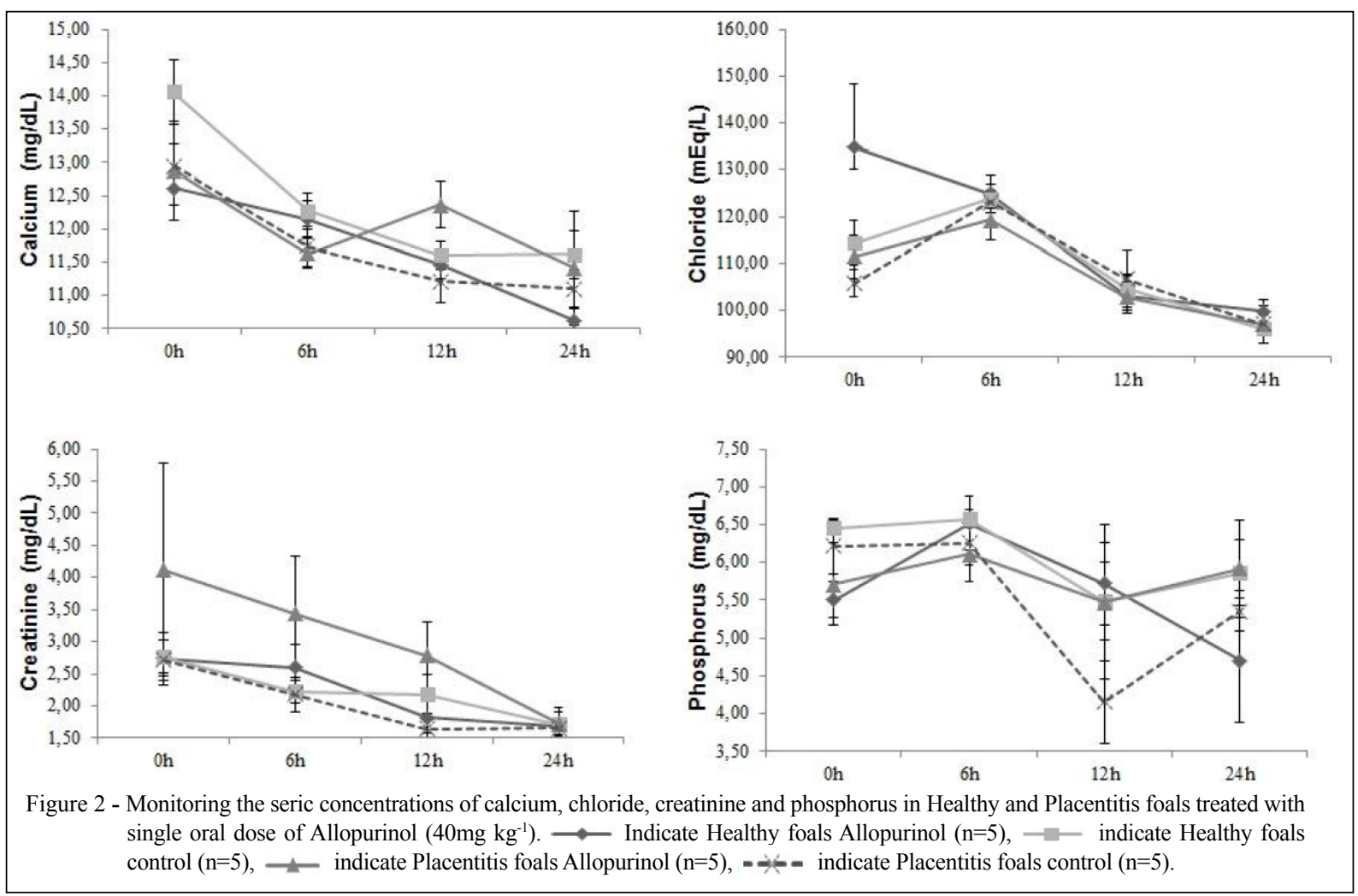

higher at 12 hours $(\mathrm{P}<0.05)$ with a reduction at 24 hours. Maintenance of values during the 6 and 12 hours time-points may indicate that administration of allopurinol may attenuate/prevent brain damage. Hypocalcemia is commonly observed in foals suffering of neonatal asphyxia, as a result of kidney damage due to a reduction in perfusion (SCHOTT, 2011). There was no difference in the levels of chloride, magnesium and phosphorus between the groups after six hours. Although, treated Placentitis foals had constant levels of phosphorus from 6 hours, while the Placentitis foals of the untreated group had a decrease in values in 12 hours. In the first days of life phosphorus concentrations are similar to the values of adult animals. Increased concentrations of phosphorus can occur in foals that suffered neonatal asphyxia due to cellular injury (KOTERBA, 1990). Electrolyte levels in foals are kept within a relatively narrow range during the first six months of life, and abnormal values at birth reflect an altered and/or abnormal uterine environment or placental function (WILKINS, 2013; AUSTIN, 2013).

Additional studies on the use and effectiveness of treatment with allopurinol have measured specific enzymes and markers of brain damage and oxidative stress generated during a hypoxic-ischemic process. In a study conducted in newborn piglets undergoing controlled hypoxia, the beneficial effects of allopurinol were demonstrated, after intravenous administration one hour after a hypoxic-ischemic event, by reducing cerebral edema in relation to the control group (PEETERSSCHOLTE et al., 2003). Other markers of brain damage and oxidative stress have been extensively studied in human neonates by the assessment of pro-oxidant, total antioxidant capacity and lipid peroxidation by measuring the plasma levels of the iron binding proteins, uric acid and malondialdehyde (VAN BEL et al., 1998).

\section{CONCLUSION}

We concluded that the use of a single dose of allopurinol PO in neonatal foals born from mares with placentitis did not cause adverse effects in hematology and serum biochemistry and can help to stabilize the levels of calcium and glucose after treatment. Thus, further studies are necessary to understand the therapeutic use of Allopurinol in neonatal foals.

Ciência Rural, v.46, n.6, jun, 2016. 

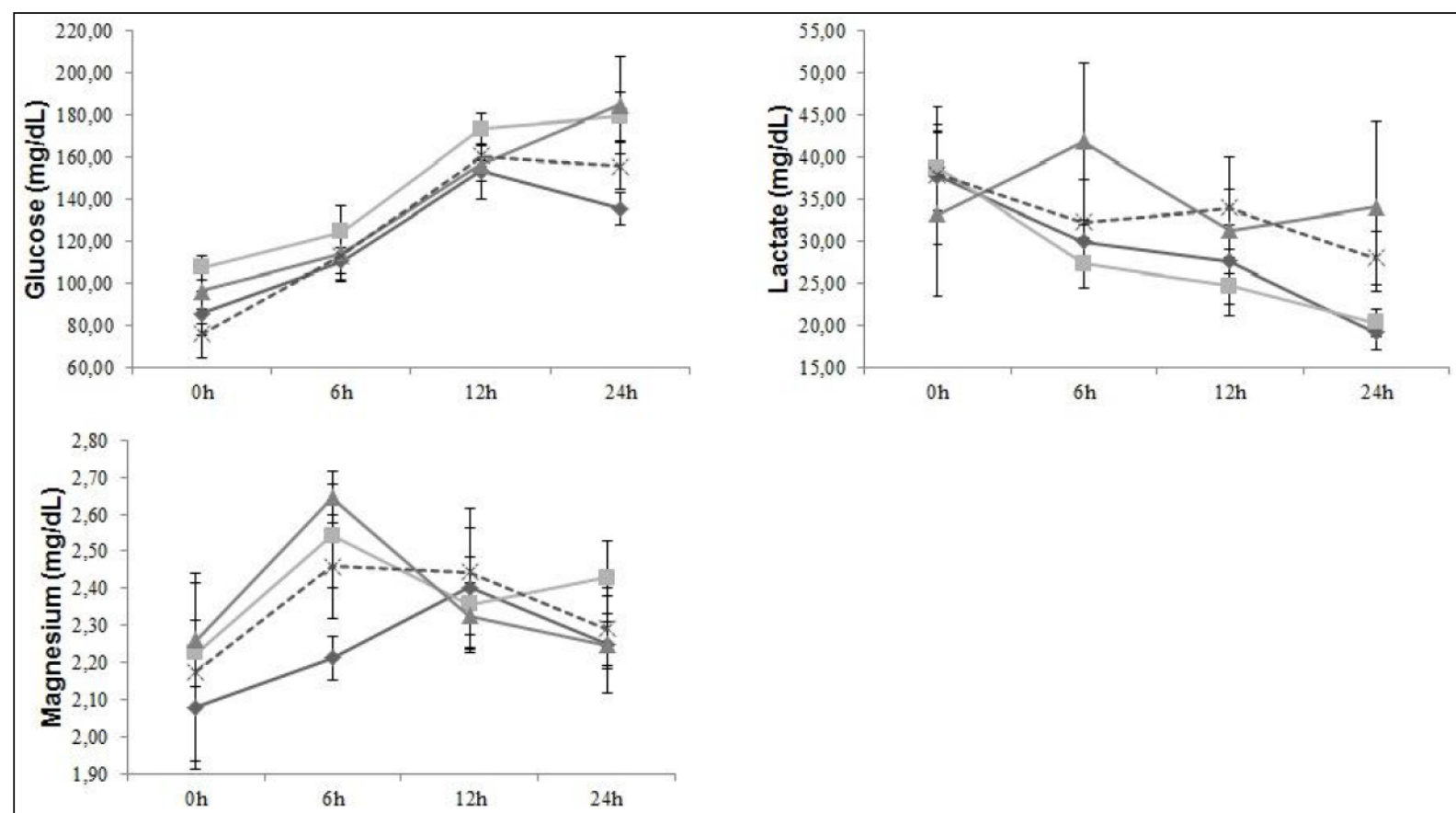

Figure 3 - Monitoring the seric concentrations of glucose, lactate and magnesium in Healthy and Placentitis foals treated with single oral dose of Allopurinol $\left(40 \mathrm{mg} \mathrm{kg}^{-1}\right)$. $\longrightarrow$ Indicate Healthy foals Allopurinol $(\mathrm{n}=5), \longrightarrow$ indicate Healthy foals control $(\mathrm{n}=5)$, $-\quad$ indicate Placentitis foals Allopurinol $(n=5),-\rightarrow-$ indicate Placentitis foals control $(n=5)$.

\section{ACKNOWLEDGEMENTS}

The authors acknowledge the staff of Santa Maria de Araras Farm for constant support and attention in the development of this project. This study was supported by the Coordenação de Aperfeiçoamento de Pessoal de Nível Superior (CAPES), Ministério da Educação, Brasília - DF, Brazil; Fundação de Amparo à Pesquisa do Estado do Rio Grande do Sul (FAPERGS), Conselho Nacional de Desenvolvimento Científico e Tecnológico (CNPq).

\section{BIOETHICS AND BIOSSECURITY COMMITEE APPROVAL}

All procedures on the animals were carried out with the approval of the Ethical Committee on Animal Experimentation of the Universidade Federal de Pelotas (UFPel) under protocol number 0125 .

\section{REFERENCES}

AUSTIN, S.M. Assessment of the equine neonate in ambulatory practice. Equine Veterinary Education, v.25, p.585-589, 2013. Available from: <http://onlinelibrary.wiley.com/doi/10.1111/ eve.12064/pdf>. Accessed: Mar. 15, 2014. doi: 10.1111/eve.12064.

BAIN, F.T. Management of the foal from the mare with placentitis: a clinician's approach. In: ANNUAL CONVENTION OF THE AMERICAN ASSOCIATION OF EQUINE PRACTITIONERS, 50, 2004, Denver, Colorado. Proceedings... Denver: Annual Convention of the AAEP, 2004. p.1419.1204. Available from:
$<$ http://www.ivis.org/proceedings/AAEP/2004/Bain/chapter. asp?LA=1>. Accessed: Sept. 15, 2013.

BENDERS, M.J. et al. Early postnatal allopurinol does not improve short term outcome after severe birth asphyxia. Archives of Disease in Childhood. Fetal and Neonatal Edition, v.91, n.3, p.163-165, 2006. Available from: <http://www.ncbi.nlm.nih.gov/ pmc/articles/PMC2672696/pdf/F163.pdf>. Accessed: Mar. 04, 2014. doi: 10.1136/adc.2005.086652.

BUCCA, S. Diagnosis of the compromized equine pregnancy. Veterinary Clinics of North America: Equine Practice, v.22, p.749-761, 2006. Available from: <http://www.sciencedirect.com/ science/article/pii/S074907390600054X?np=y>. Accessed: Jan. 10, 2015. doi: 10.1016/j.cveq.2006.07.006.

CORLEY, K.T. et al. Arterial lactate concentration, hospital survival, sepsis and SIRS in critically ill neonatal foals. Equine Veterinary Jornal, v.37, n.1, p.53-59, 2005. Available from: $<$ http://onlinelibrary.wiley.com/doi/10.2746/0425164054406856/ pdf>. Accessed: Mar. 15, 2014. doi: 10.2746/0425164054406856.

CURCIO, B.R.; NOGUEIRA, C.E.W. Newborn adaptations and healthcare throughout the first age of the foal. Animal Reproduction, v.9, p.182-187, 2012. Available from: <http://www. cbra.org.br/pages/publicacoes/animalreproduction/issues/download/ v9n3/pag182-187\%20(AR517).pdf >. Accessed: Mar. 24, 2013.

GONZALES, F.F.; FERRIERO, D.M. Neuroprotection in the newborn infant. Clinical Perinatology, v.36, p.859-880, 2009. Available from: <http://www.sciencedirect.com/science/article/pii/ S0095510809000694\#>. Accessed: Mar. 24, 2014. doi: 10.1016/j. clp.2009.07.013. 
HONG, C.B. et al. Etiology and pathology of equine placentitis. Journal of Veterinary Diagnostic Investigation, v.5, p.55-63, 1993.

INDER, T.E.; VOLPE, J.J. Mechanism of perinatal brain injury. Seminars in fetal and Neonatal medicine, v.5, p.3-16, 2000. Available from: <http://www.sciencedirect.com/science/article/ pii/S1084275699901124>. Accessed: Jun. 20, 2015. doi: 10.1053/ siny.1999.0112.

KOTERBA, A.M. Neonatal asfixia. In: KOTERBA, A.M. et al. Equine clinical neonatology. Philadelphia: Lea \& Febiger, 1990. Cap.9, p.124-135.

McAULIFFE, S.B. Neonatal examination, clinical procedures and nursing care. In: McAULIFFE, S.B.; SLOVIS, N.M. Atlas of diseases and disorders of the foal. Philadelphia: Saunders Elsevier, 2008. Cap.3, p.132-165.

MOREL, M.C.G.D. et al. Factors affecting gestation length in the Thoroughbred mare. Animal Reproduction Science, v.74, p.175-185, 2002. Available from: <http://www.sciencedirect. com/science/article/pii/S0378432002001719>. Accessed: Jun. 20, 2015. doi: 10.1016/S0378-4320(02)00171-9.

PEETERS-SCHOLTE, C. et al. Effects of allopurinol and deferoxamine on reperfusion injury of the brainin newborn piglets after neonatal hypoxia-ischemia. Pediatric Research, v.54, p.516522, 2003. Available from: <http://www.nature.com/pr/journal/ v54/n4/abs/pr2003462a.html>. Accessed: Jun. 20, 2015. doi: 10.1203/01.PDR.0000081297.53793.C6.
RENAUDIN, C.D. et al. Ultrasonographic evaluation of the equine placenta by transrectal and transabdominal approach in the normal pregnant mare. Theriogenology, v.47, p.559573, 1997. Available from: <http://dx.doi.org/10.1016/S0093691X(97)00014-9>. Accessed: Sept. 20, 2013. doi: 10.1016/ S0093-691X(97)00014-9.

SCHOTT, H.C. Review of azotemia in foals. In: ANNUAL CONVENTION OF THE AMERICAN ASSOCIATION OF EQUINE PRACTITIONERS, 57., 2011, San Antonio, Texas. Proceedings... San Antonio: Annual Convention of the AAEP, 2011. p.328-334. Available from: <http://www.ivis.org/ proceedings/aaep/2011/328.pdf $>$. Accessed: Sept. 15, 2013.

VAALA, W.E. Peripartum asphyxia syndrome in foals. In: ANNUAL AMERICAN ASSOCIATION EQUINE PRACTITIONERS CONVENTION, 45., 1999, Albuquerque, New Mexico. Proceedings... Albuquerque: Annual Convention of the AAEP, 1999. p.247-253. Available from: <http://www.ivis.org/ proceedings/AAEP/1999/247.pdf>. Accessed: Sept. 15, 2013.

VAN BEL, F. et al. Effect of allopurinol on postasphyxial free radical formation, cerebral hemodynamics, and electrical brain activit. Pediatrics, v.101, p.185-193, 1998.

WILKINS, P.A. The equine neonatal intensive care laboratory: point-of-care testing. Clinics in Laboratory Medicine, v.31, n.1, p.125-137, 2011. Available from: $<$ http://www.sciencedirect. com/science/article/pii/S0272271210001538>. Accessed: Mar. 10, 2013. doi: 10.1016/j.cll.2010.11.001. 